\title{
Effects of nitrogen supply on inter-organ fluxes of urea-N and renal urea-N kinetics in lactating Holstein cows
}

\author{
B. A. Røjen, ${ }^{1}$ P. K. Theil, and N. B. Kristensen \\ Department of Animal Health and Bioscience, Faculty of Agricultural Sciences, Aarhus University, DK-8830 Tjele, Denmark
}

\begin{abstract}
The effects of decreasing ruminal urea infusion in lactating dairy cows fed a basal diet deficient in rumen degradable protein on inter-organ urea- $\mathrm{N}$ fluxes, epithelial urea- $\mathrm{N}$ extraction, and renal urea- $\mathrm{N}$ kinetics were investigated. Eight Danish Holstein cows fitted with a ruminal cannula and permanent indwelling catheters in the major splanchnic blood vessels and the gastrosplenic vein were used. The cows were randomly allocated to a triplicate incomplete $3 \times 3$ Latin square design with 14 -d periods. Treatments were continuous ventral ruminal infusion of water, $4.1 \mathrm{~g}$ of feed urea/ $\mathrm{kg}$ of dry matter intake, and $8.5 \mathrm{~g}$ of feed urea $/ \mathrm{kg}$ of dry matter intake. Dry matter intake and milk yield decreased linearly with decreasing urea infusion. Arterial blood urea-N and ruminal ammonia concentrations decreased linearly with decreasing urea infusion. In absolute amounts, the urea- $\mathrm{N}$ recycling did not increase when urea infusion was decreased. Arterial urea-N extraction across the portal-drained viscera and rumen wall increased linearly with decreasing urea infusion $(2.46,3.65$, and $4.32 \pm 0.31 \%$ and $7.5,11.5$, and $16.9 \pm$ $0.9 \%$, respectively), indicating that cows responded to the changes in $\mathrm{N}$ supply. The relative urea- $\mathrm{N}$ extraction across the ruminal wall increased compared with the total portal-drained viscera extraction. We observed a postprandial decrease in ruminal extraction of arterial urea- $\mathrm{N}$ that might reflect that the activity of the protein, presumably facilitating urea- $\mathrm{N}$ transport, is regulated by ruminal ammonia. The urea- $\mathrm{N}$ clearance by the kidneys decreased $(35,30$, and $25 \pm 2 \mathrm{~L} / \mathrm{h})$ and the urea- $\mathrm{N}$ reabsorbed by the kidney increased $(42,51$ and $56 \pm 3 \%$ ) with decreasing urea infusion, indicating that the kidneys salvaged urea-N with low-N supply. The urea transporter B mRNA abundance in rumen papillae (papillae harvested at sampling days) was not affected by dietary $\mathrm{N}$ supply. The study showed, that rumen wall extraction of arterial urea- $\mathrm{N}$ is subjected to both long- and short-term regulation. Extraction increases
\end{abstract}

Received October 20, 2010.

Accepted January 17, 2011.

${ }^{1}$ Corresponding author: Betina.AmdisenRojen@agrsci.dk with decreasing N supply long-term; however, a shortterm postprandial decrease in extraction was observed. No association between long-term adaptation of urea-N extraction across the rumen wall and urea transporter B mRNA abundance could be demonstrated.

Key words: dairy cow, metabolism, urea-N recycling, UT-B urea transporter

\section{INTRODUCTION}

Ruminants are able to recycle endogenous urea-N to the gastrointestinal tract (Nolan and Leng, 1972). In the rumen, urea- $\mathrm{N}$ can be utilized for microbial protein synthesis and compensate for $\mathrm{N}$ losses associated with AA deamination and subsequent absorption of ammonia to the blood (Lapierre and Lobley, 2001), the inevitable loss of $\mathrm{N}$ related to the endogenous AA catabolism (Lobley et al., 2003), and microbial sequestration of $\mathrm{N}$ in purines and pyrimidines (Kristensen et al., 2010). Recycling of urea- $\mathrm{N}$ appears more efficient in ruminants fed low-N compared with high-N diets. With low-N diets a higher proportion of urea- $\mathrm{N}$ is recycled to the gastrointestinal tract (Marini and Van Amburgh, 2003; Marini et al., 2004). Despite the potential beneficial effect of urea- $\mathrm{N}$ recycling on $\mathrm{N}$ efficiency, practical dairy farming operations utilize only approximately $25 \%$ of dietary $\mathrm{N}$ in milk protein output, weight gain, and fetal growth (Børsting et al., 2003; Huhtanen and Hristov, 2009). The mechanism by which the urea- $\mathrm{N}$ flux across the gut epithelia of ruminants is regulated remains equivocal. Previous studies showed a linear relationship between blood plasma concentrations of urea- $\mathrm{N}$ and the transfer of urea-N across gut epithelia (Houpt, 1970; Sunny et al., 2007; Kristensen et al., 2010), indicative of a mass action regulated transport of urea-N. However, in dietary intervention experiments, a decreased extraction of arterial urea-N with increasing arterial urea-N concentration has been observed (Calsamiglia et al., 2010), suggesting that epithelial urea-N transport is subject to a long-term (weeks) adaptation to $\mathrm{N}$ status. This adaptation to dietary-induced changes in $\mathrm{N}$ supply results in changes in the permeability and extraction ratio of urea- $\mathrm{N}$ across gut epithelia, although when expressed in absolute amounts, the urea- $\mathrm{N}$ transport to 
the gut has been little affected by changes in dietary $\mathrm{N}$ intake (Marini and Van Amburgh, 2003; Calsamiglia et al., 2010). Urea transporter B (UT-B) was found to be expressed in ruminal epithelium (Stewart et al., 2005) and indicates that urea transporters might be involved in regulating the epithelial flux of urea-N. Data on UT-B expression in gut epithelia as a function of dietary $\mathrm{N}$ concentration have been diverging (Marini and Van Amburgh, 2003; Marini et al., 2004; Ludden et al., 2009).

We hypothesized that cows challenged with a diet low in RDP supply would be able to compensate for low- $\mathrm{N}$ intake by increasing the urea- $\mathrm{N}$ flux from blood to gut. The aim of the present study was to challenge lactating dairy cows with decreasing RDP supply by decreasing the amount of continuous intraruminally infused urea to a basal diet low in RDP and to investigate the potential contribution from urea-N recycling to compensate for decreased RDP supply. We also aimed to investigate the relationship between arterial blood urea- $\mathrm{N}$ concentration and portal-drained visceral (PDV) and ruminal extraction ratios of arterial urea- $\mathrm{N}$, as well as the abundance of UT-B mRNA in the epithelia of ruminal papillae in cows supplied with decreasing RDP.

\section{MATERIALS AND METHODS}

The present experiment complied with the Danish Ministry of Justice, Law no. 382 (June 10, 1987), Act no. 726 (September 9, 1993) concerning experiments with animals and care of experimental animals.

\section{Animals and Experimental Design}

Eight lactating Danish Holstein were used. Cows were $39 \pm 2$ DIM in their second lactation at the beginning of the study. The cows were fitted with a ruminal cannula (10 cm; Bar Diamond Inc., Parma, ID) and permanent indwelling catheters in an artery, mesenteric vein, hepatic portal vein, and hepatic vein, as described previously (Larsen and Kristensen, 2009). An additional catheter was implanted in the gastrosplenic vein by dissecting a small branch of the right ruminal vein on the right face of the caudoventral blind sac. The catheter was passed dorso-cranially along the ascending right ruminal vein following the right ventral coronary groove and the tip was placed in the gastrosplenic vein. The gastrosplenic vein catheter was made of silicone tubing (Saint Gobain STHT-C-040-0F, 1.02 i.d. × 2.18 mm o.d.; Colly FlowTech AB, Kista, Sweden). Several cuffs of silicone glue were placed 42 to $55 \mathrm{~cm}$ from the catheter tip to aid in fixing the catheter.

The cows were kept in tie stalls with rubber mats and wood shavings as bedding. The cows were milked at 0530 and $1530 \mathrm{~h}$ and milk production was recorded at each milking. The cows were randomly allocated to a triplicate incomplete $3 \times 3$ Latin square design with 14 -d periods. Treatments were ventral ruminal infusion of tap water (water infusion, $10 \mathrm{~L} / \mathrm{d}$ ), ventral ruminal infusion of $4.1 \mathrm{~g}$ of feed urea $/ \mathrm{kg}$ of DMI, and ventral ruminal infusion of $8.5 \mathrm{~g}$ of feed urea $/ \mathrm{kg}$ of DMI.

All cows were fed the same basal TMR (Table 1), formulated using the Scandinavian feed evaluation system (NorFor; http://www.norfor.info). The RDP supply of basal TMR was estimated to be $18 \mathrm{~g} / \mathrm{kg}$ of DM below minimum requirements and, consequently, supplied only $80 \%$ of requirements for MP. The basal TMR adequately supplied other nutrients except for marginal undersupply of $\mathrm{P}$ and $\mathrm{Ca}$. The first week of each experimental period the basal diet was fed to obtain approximately $10 \%$ orts and voluntary DMI for each cow was determined as the average DMI during this period. Each cow was fed at $95 \%$ of her voluntary DMI for the reminder of the experimental period to ensure constant daily intake to obtain the predefined urea infusion relative to DMI. Cows were fed 3 equal portions at 0800,1600 , and $2400 \mathrm{~h}$ to allow for an 8-h sampling window and orts were removed and weighed at $0730 \mathrm{~h}$. Feed samples were collected daily for DM determination and stored at $-20^{\circ} \mathrm{C}$. Cows had access to salt mineral blocks (Salto Universal; Vitfoss, Gråsten, Denmark).

The infusates were prepared daily and the amount of feed urea (SKW Stickstoffwerke Piesteritz GMBH, Lutherstadt Wittenberg, Germany) for infusion was calculated each day according to DMI the previous 24 h. Urea infusion rates were changed on the first day of each experimental period. Infusions were continuous for $24 \mathrm{~h}$ except for about $20 \mathrm{~min}$ in the afternoon during mixing of new infusates. Water and feed urea were added to 10-L jerry cans and mixed to ensure that feed urea was completely dissolved. Adjustablespeed 2-channel peristaltic pumps (Type 115, Ole Dich Instrumentmakers, Hvidovre, Denmark), mounted with silicone tubing (3 mm i.d., $6 \mathrm{~mm}$ o.d.; Ole Dich Instrumentmakers) were used for the ruminal infusions (413 $\pm 1 \mathrm{~g}$ of infusate/h). Infusion lines were inserted through the ruminal cannula and a weight fastened at the tip of the tubing was used to anchor the infusion tubing in the ventral ruminal sack. Several small holes were made 18 to $8 \mathrm{~cm}$ from the tip of the tubing to allow diffusion into ruminal contents.

\section{Experimental Samplings}

Blood flows were determined by downstream dilution of $p$-aminohippuric acid (pAH) according to Katz and Bergman (1969). p-Aminohippuric acid (175 mmol/kg) 
was infused continuously into the mesenteric vein at $28 \pm 2 \mathrm{mmol} / \mathrm{h}$. The infusion was initiated at 0530 $\mathrm{h}$ (except in period 1 where infusions were initiated at $0630 \mathrm{~h}), 2 \mathrm{~h}$ before first urine sampling, to ensure that urine concentration of $\mathrm{pAH}$ had reached steady state at first sampling. Quasi steady state conditions for $\mathrm{pAH}$ in blood were ensured by visual inspection of plots of plasma pAH concentrations versus time. Eight sets of blood, ruminal fluid, and urine samples were obtained at $0.5 \mathrm{~h}$ before feeding and at $0.5,1.5,2.5$, $3.5,4.5,5.5$, and $6.5 \mathrm{~h}$ after feeding. Before blood sampling, catheters were primed by drawing a minimum of 2 times the catheter volume into a blank syringe and the blood discarded. Blood was sampled simultaneously from the artery, hepatic portal vein, and hepatic vein by slowly drawing blood into $20-\mathrm{mL}$ syringes, followed by sampling of gastrosplenic blood into 5 -mL syringes. Blood was transferred into sodium heparin vacuettes (Greiner Bio-One GmbH, Kremsmünster, Austria) and $\mathrm{K}_{3}$ EDTA vacuettes (Greiner Bio-One $\mathrm{GmbH}$ ) and placed on crushed ice immediately after collection. Separate blood samples were collected in 1-mL heparinized syringes for blood gas measurements. Plasma was harvested after centrifugation at $3,000 \times g$ at $4^{\circ} \mathrm{C}$ for 20 min and stored at $-20^{\circ} \mathrm{C}$ until analysis. Ruminal fluid was sampled from the ventral ruminal sack through the rumen cannula using an extended suction strainer (Bar Diamond) and a 60-mL syringe. A subsample of ruminal fluid was stabilized with meta-phosphoric acid (5\% final concentration) and stored at $-20^{\circ} \mathrm{C}$. Eight samples of urine were collected at the same time points as blood sampling by stimulating the cow to urinate in a cup by sweeping the supra mammary region by hand. Subsamples were stored at $-20^{\circ} \mathrm{C}$.

At 1100 to $1200 \mathrm{~h}$, ruminal mucosa from the lateral face of the cranioventral sac (atrium) was biopsied through the rumen cannula by snapping off 15 to 20 papillae by hand, and papillae were submerged in RNA stabilization solution (RNAlater; Sigma-Aldrich Inc., St. Louis, MO) in 2.0-mL Eppendorf tubes, stored at $4^{\circ} \mathrm{C}$ overnight, and then transferred to $-80^{\circ} \mathrm{C}$. Milk samples were collected on sampling days. Feces were sampled morning and afternoon the day before and on the day of sampling. Feces samples were collected in 250-mL screw cap containers (\#75.9922.532; Sarstedt AG \& Co., Nümbrecht, Germany) and stored at $-20^{\circ} \mathrm{C}$ until analysis. Cows were weighed before the afternoon milking on sampling days.

\section{Analytical Procedures}

Feed DM was determined by drying at $60^{\circ} \mathrm{C}$ for 48 $\mathrm{h}$ in a forced-air oven. Feed samples from the last $7 \mathrm{~d}$ of each experimental period were pooled for chemical
Table 1. Ingredient and nutrient composition of basal diet $(\mathrm{g} / \mathrm{kg}$ of DM, unless otherwise noted)

\begin{tabular}{|c|c|}
\hline Item & $\begin{array}{c}\text { Experimental } \\
\text { diet }\end{array}$ \\
\hline \multicolumn{2}{|l|}{ Ingredient } \\
\hline Corn silage ${ }^{1}$ & 475 \\
\hline Grass clover silage $^{2}$ & 185 \\
\hline Sodium hydroxide treated wheat grain & 155 \\
\hline Rapeseed cake, $13 \%$ fat & 100 \\
\hline Molasses, sugar beet & 10 \\
\hline Sugar beet pulp, dried & 64 \\
\hline Mineral premix & 10 \\
\hline Chromium(III)oxide & 1 \\
\hline \multicolumn{2}{|l|}{ Nutrient } \\
\hline $\mathrm{DM}, \mathrm{g} / \mathrm{kg}$ & $416 \pm 12$ \\
\hline Ash & $65.1 \pm 2.66$ \\
\hline NDF & $307 \pm 2.6$ \\
\hline Crude fat & $42.0 \pm 1.21$ \\
\hline $\mathrm{CP}$ & $126 \pm 3$ \\
\hline \multicolumn{2}{|l|}{ Calculated nutrient composition } \\
\hline $\mathrm{RDP}^{4}$ & 83 \\
\hline $\mathrm{MP}(\text { NorFor AAT })^{4}$ & 79 \\
\hline $\mathrm{NE}_{\mathrm{L}},{ }^{4} \mathrm{MJ} / \mathrm{kg}$ of $\mathrm{DM}$ & 6.84 \\
\hline
\end{tabular}

${ }^{1}$ Chemical composition of corn silage: DM, 363 (g/kg); ash, 31; CP, 87; NDF, 375; starch, 320; in vitro OM digestibility, $72.5 \%$.

${ }^{2}$ Chemical composition of grass clover silage: DM, 407 (g/kg); ash, 86; CP, 146; NDF, 363; in vitro OM digestibility, $78.8 \%$.

${ }^{3}$ Mineral mix (VM 1; Vitfoss, Gråsten, Denmark) contained (per kg) $180 \mathrm{~g}$ of $\mathrm{Ca}, 4 \mathrm{~g}$ of P, $65 \mathrm{~g}$ of $\mathrm{Mg}, 80 \mathrm{~g}$ of $\mathrm{Na}, 30 \mathrm{~g}$ of S, $693 \mathrm{kIU}$ of vitamin A, $146 \mathrm{kIU}$ of vitamin $\mathrm{D}, 4,620 \mathrm{mg}$ of $\alpha$-tocopherol, 3,080 mg of $\mathrm{Mn}, 693 \mathrm{mg}$ of $\mathrm{Cu}, 19 \mathrm{mg}$ of $\mathrm{Co}, 3,460 \mathrm{mg}$ of $\mathrm{Zn}, 173 \mathrm{mg}$ of I, and $38.5 \mathrm{mg}$ of Se.

${ }^{4}$ Calculated using the Nordic Feed Evaluation System (NorFor; http:// www.norfor.info).

analysis. Organic matter was determined as DM - crude ash, where crude ash was determined after combustion at $525^{\circ} \mathrm{C}$ for $6 \mathrm{~h}$. Crude fat was determined as petroleum ether extract following acid hydrolysis (Stoldt, 1952). Neutral detergent fiber content was determined as described by Mertens (2002). Crude protein was determined as $\mathrm{N} \times 6.25$, and $\mathrm{N}$ determined by the Dumas method as described by Hansen (1989).

Packed cell volume was determined for all arterial samples by centrifugation of microcapillary tubes at $13,000 \times g$ for $6 \mathrm{~min}$ at ambient temperature. Blood collected in 1-mL syringes was immediately taken for blood gas and oximetry analysis (ABL 520; Radiometer A/S, Copenhagen, Denmark). Plasma and rumen fluid concentrations of D-glucose and L-lactate were determined by immobilized oxidase enzyme membranes and ion-selective electrodes using a Select Biochemistry Analyzer (YSI 7100, YSI Inc., Yellow Springs, OH). Plasma and urine concentrations of pAH were determined by the method described by Kristensen et al. (2009a) using a continuous flow analyzer (AutoAnalyzer 3; method US-216-17 rev.1, SEAL Analytical Ltd., Burgess Hill, UK). Plasma, urine, and milk urea-N concentrations were determined using the diacetyl monoxime method 
(Marsh et al., 1965) using a continuous flow analyzer. Before analysis, milk was deproteinized by combining raw milk samples with an equal volume of $24 \%$ TCA. Concentrations of ammonia, BHBA, and NEFA were determined in plasma using a Cobas Mira autoanalyzer (Triolab A/S, Brøndby, Denmark) and kits based on glutamate dehydrogenase (AM 1015, Randox Laboratories Ltd., Crumlin, UK), D-3-hydroxybutyrate dehydrogenase (Ranbut, Randox Laboratories Ltd.), and the acyl coenzyme A (CoA) synthetase/acyl CoA oxidase method (FA 115, Randox Laboratories Ltd.), respectively. Arterial plasma and urine concentrations (1:20 dilution) of creatinine- $\mathrm{N}$ were determined using a Cobas Mira autoanalyzer and a kit based on reaction with alkaline picrate (Creatinine $120 \mathrm{CP}$; Horiba ABX, Montpellier, France).

Ruminal fluid $\mathrm{pH}$ was measured immediately after sampling using a combination electrode (PHC2002-8; Hach Lange APS, Brønshøj, Denmark) and a pH meter calibrated at pH 4.005 and 7.000 (PHM 240; Hach Lange APS). Ruminal fluid with 5\% metaphosphoric acid was analyzed for VFA by gas chromatography (Kristensen et al., 1996). Ammonia in ruminal fluid was determined using a Cobas Mira autoanalyzer after 1:20 dilution with $100 \mathrm{~m} M$ phosphate buffer by using a kit (AM 1015, Randox Laboratories Ltd.).

Urine $\mathrm{pH}$ was measured immediately after collection as described for ruminal fluid. Total $\mathrm{N}$ in urine was determined as described by Hansen (1989). Urine samples collected $0.5 \mathrm{~h}$ before and 1.5, 3.5, and $5.5 \mathrm{~h}$ after feeding were analyzed for hippuric acid and amino acid-N (alanine, glycine, leucine, isoleucine, proline, and valine) by GC-MS using adipic acid as internal standard (Kristensen et al., 2009b).

Feces were analyzed for DM, CP, ash, and NDF according to the same procedures as feed. Milk was analyzed for the content of protein, fat, and lactose by infrared spectroscopy using a Milkoscan 4000 (Foss Electric, Hillerød, Denmark). Urine concentrations of allantoin- $\mathrm{N}$ and uric acid- $\mathrm{N}$ were determined by liquid chromatography according to Thode (1999).

Quantification of mRNA abundance in rumen papillae was carried out by real-time reverse transcriptase PCR (real-time RT-PCR). Briefly, rumen papillae were homogenized and RNA was purified using the RNeasy mini kit (Qiagen, Albertslund, Denmark) according to manufacturer's protocol. The concentration of total RNA was determined by measuring the absorbance at $260 \mathrm{~nm}$. Purified RNA was reverse transcribed with oligo-dT and random primers and Superscript II RNase $\mathrm{H}$ reverse transcriptase kit (Invitrogen, Taastrup, Denmark), and the cDNA was amplified with TaqMan Universal PCR Master Mix (Applied Biosystems, Stockholm, Sweden), using SYBR green nonspecific detection, and primers specific for UT-B. Primers were designed by using Primer Express 2.0 software (Applied Biosystems). The oligonucleotide sequences of forward and reverse primers for UT-B (NCBI Accession \#: AY624602)

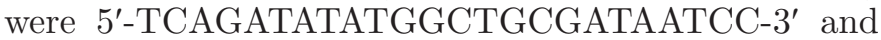
5'-AGCTGAAAGACTGAGTCCTGCTATT-3' ${ }^{\prime}$, respectively, and the underlined nucleotides denotes the splice site. Normalization of UT-B mRNA abundance was accomplished using GAPDH as the housekeeping gene (NCBI Accession \#: AB098934). Following RT-PCR amplification, melting curve analysis was performed to ensure the quality of amplification.

\section{Calculations and Statistics}

Whole-blood concentrations of ammonia were set equal to blood plasma concentrations. The whole-blood concentration of urea- $\mathrm{N}$ was obtained by correcting for the urea dilution space in erythrocytes of $80 \%$. The urea dilution space in erythrocytes was determined by the method described previously for VFA by Kristensen (2000). In short, whole blood was spiked with known amounts of urea and effective dilution volume in the erythrocyte fraction was determined by measuring urea concentrations in plasma harvested using the same centrifugation procedure as used for the experimental samples. Calculations of net portal, net hepatic, and total splanchnic metabolite fluxes, and PDV extraction ratio of urea- $\mathrm{N}$ were performed as described by Røjen et al. (2008a). A positive net flux indicates a net release from a tissue to the blood, whereas a negative net flux indicates a net uptake by the tissue. The ruminal extraction ratio of urea- $\mathrm{N}$ was calculated as (arterial blood concentration of urea-N - gastrosplenic blood concentration of urea-N) / arterial blood concentration of urea-N. Diuresis was calculated as the infusion rate of pAH / urinary concentration of pAH. The renal plasma flow was calculated as the infusion rate of pAH / arterial plasma concentration of pAH, assuming complete renal extraction of pAH at first passage. Metabolite excretion rates in urine were calculated as diuresis $\times$ concentration of specific metabolites. Urea$\mathrm{N}$ clearance (volume of blood urea- $\mathrm{N}$ cleared by the kidney per unit of time) was calculated as (urinary urea-N concentration / arterial blood concentration of urea-N) $\times$ diuresis. Creatinine-N plasma clearance was calculated as (urinary creatinine- $\mathrm{N}$ concentration / arterial plasma concentration of creatinine-N) $\times$ diuresis. The filtered load of urea- $\mathrm{N}$ (urea- $\mathrm{N}$ filtered at glomerulus) was calculated as arterial blood concentration of urea- $\mathrm{N} \times$ creatinine- $\mathrm{N}$ clearance. Urea- $\mathrm{N}$ reabsorption in percent was calculated as [(filtered load of urea-N - urinary urea-N excretion)/ filtered load of urea-N] $\times 100$. 
To evaluate mRNA abundance, data was obtained as $\mathrm{Ct}$ values (the number of PCR cycles required to reach a certain threshold) according to Theil et al. (2006). Least squares means of $\Delta \mathrm{Ct}$ values $(\Delta \mathrm{Ct}=\mathrm{Ct}$ of the target gene - Ct of the housekeeping gene) were normalized to the level observed when infusing $0 \mathrm{~g}$ of urea $/ \mathrm{kg}$ of DMI by calculating the $\Delta \Delta \mathrm{Ct}$ values ( $\Delta \mathrm{Ct}$ observed at given treatment $-\Delta \mathrm{Ct}$ observed at treatment $0 \mathrm{~g}$ of urea/ $\mathrm{kg}$ of DMI), and the relative mRNA abundance was calculated as $\mathrm{E}^{-\Delta \Delta \mathrm{Ct}}$, where $\mathrm{E}$ is $1+\mathrm{PCR}$ efficiency as determined by $10^{-1 / \text { slope of standard curve }}-1$. To exclude potential bias because of averaging data that had been transformed through the equation $\mathrm{E}^{-\Delta \Delta \mathrm{Ct}}$, all statistics were performed at the $\Delta \mathrm{Ct}$ level.

Data on blood, ruminal, and urine variables were analyzed using the MIXED procedure of SAS [version 9.1 (TS1M3), SAS Institute Inc., Cary, NC] according to a triplicate incomplete $3 \times 3$ Latin square design with treatment, period, sampling time (time), and the interaction treatment $\times$ time as fixed effects. Cow within square and square were considered random effects. Sampling times were considered as repeated measures. Covariance structures were modeled using compound symmetry, heterogeneous autoregressive order 1, heterogeneous Toeplitz, and first-order factor analytics based on model convergence and fit statistics. Orthogonal contrasts were used to estimate linear and quadratic effects of treatments. Variables with only one observation within cow and sampling day were analyzed using a reduced model, not including the effect of time. Data on DMI and milk yield were analyzed using data from the last $4 \mathrm{~d}$ of the period. There were missing values: 2 cows had no functional gastrosplenic vein catheter. In period 1, 1 cow had missing gastrosplenic blood samples. In period 2, 1 cow was missing gastrosplenic blood samples 2 and 3 , and in period 3 one cow was missing sample 1 . One cow was removed from the trial in period 3 for reasons not related to treatments. Data are reported as least squares means \pm residual standard errors of the mean. Significance was declared at $P \leq 0.05$ and tendencies were considered at $0.05<$ $P \leq 0.10$.

\section{RESULTS}

\section{Diet Composition and Feed Intake}

The total N supply with feed plus infused urea-N was equivalent to dietary $\mathrm{CP}$ concentrations of $12.6,13.8$, and $15.0 \%$ of $\mathrm{DM}$ for the 3 experimental treatments. Dry matter intake and $\mathrm{CP}$ digestibility decreased linearly $(P<0.01$; Table 2$)$ with decreasing urea infusion. A quadratic effect of urea infusion on CP digestibil- ity $(P<0.01)$ was found, reflecting a relatively small difference between 8.5 and $4.1 \mathrm{~g}$ of urea $/ \mathrm{kg}$ of DMI compared with a larger decrease when decreasing urea infusion from 4.1 to $0 \mathrm{~g} / \mathrm{kg}$ of DMI. Neither NDF nor OM digestibility differed among treatments and averaged $40 \pm 7$ and $65 \pm 3 \%$, respectively.

\section{Milk Yield, Milk N Efficiency, and BW}

Decreasing urea infusion linearly decreased milk yield $(P=0.02$; Table 2$)$ and milk solids yield $(P=0.02$ to $0.04)$. The milk urea-N concentration decreased linearly $(P<0.01)$, and milk lactose concentration tended to increase $(P=0.10)$ with decreasing urea infusion. Milk fat and protein contents were not affected by treatment. Dietary $\mathrm{N}$ supply, infused urea-N, fecal $\mathrm{N}$, apparently digested $\mathrm{N}$, urinary $\mathrm{N}$, and milk $\mathrm{N}$ decreased $(P<0.01$ to $P=0.05$ ) linearly with decreasing urea infusion. The infused feed urea accounted for 16.1 and $8.5 \%$ of total $\mathrm{N}$ supply (dietary + infused) with 8.5 and $4.1 \mathrm{~g}$ urea/ $\mathrm{kg}$ of DMI, respectively. The recovery of supplied $\mathrm{N}$ in milk increased linearly $(P<0.01)$ with decreasing urea infusion. Body weights were not affected by treatment.

\section{Ruminal Variables}

Ruminal $\mathrm{pH}$ increased linearly $(P=0.05$; Table 3$)$ and the ruminal concentration of ammonia decreased linearly $(P<0.01)$ with decreasing urea infusion. Llactate concentrations were not affected by treatment. Ruminal concentration of total VFA decreased and the molar proportion of isobutyrate increased linearly $(P<0.01)$ with decreasing urea infusion. The molar proportions of acetate, propionate, butyrate, valerate, and caproate were not affected by treatment; however, treatment by time interactions were observed $(P=0.04$ and 0.03 , respectively) for the ruminal isobutyrate and isovalerate, reflecting a less postprandial increase in water infusion compared with a more marked postprandial increase with 4.1 and $8.5 \mathrm{~g}$ of urea $/ \mathrm{kg}$ of DMI. Effects of time $(P<0.01)$ were observed for all measured ruminal variables. The ruminal $\mathrm{pH}$ decreased immediately after feeding and increased from the nadir observed at $0.5 \mathrm{~h}$ after feeding toward prefeeding levels. The molar proportion of acetate, propionate, and isovalerate increased $0.5 \mathrm{~h}$ after feeding, along with a decrease in the molar proportion of butyrate, isobutyrate, valerate, and caproate. At $1.5 \mathrm{~h}$ after feeding, the molar proportion of propionate and isovalerate continued to increase and also the molar proportions of butyrate, isobutyrate, valerate, and caproate increased, with the zenith from 2.5 to $3.5 \mathrm{~h}$ after feeding. At $1.5 \mathrm{~h}$ after feeding, the molar proportion of acetate had decreased. 
Table 2. Effect of ruminal urea infusion on DMI, nutrient digestibility, milk yield, milk composition, apparent $\mathrm{N}$ utilization for milk protein, and BW in lactating dairy cows

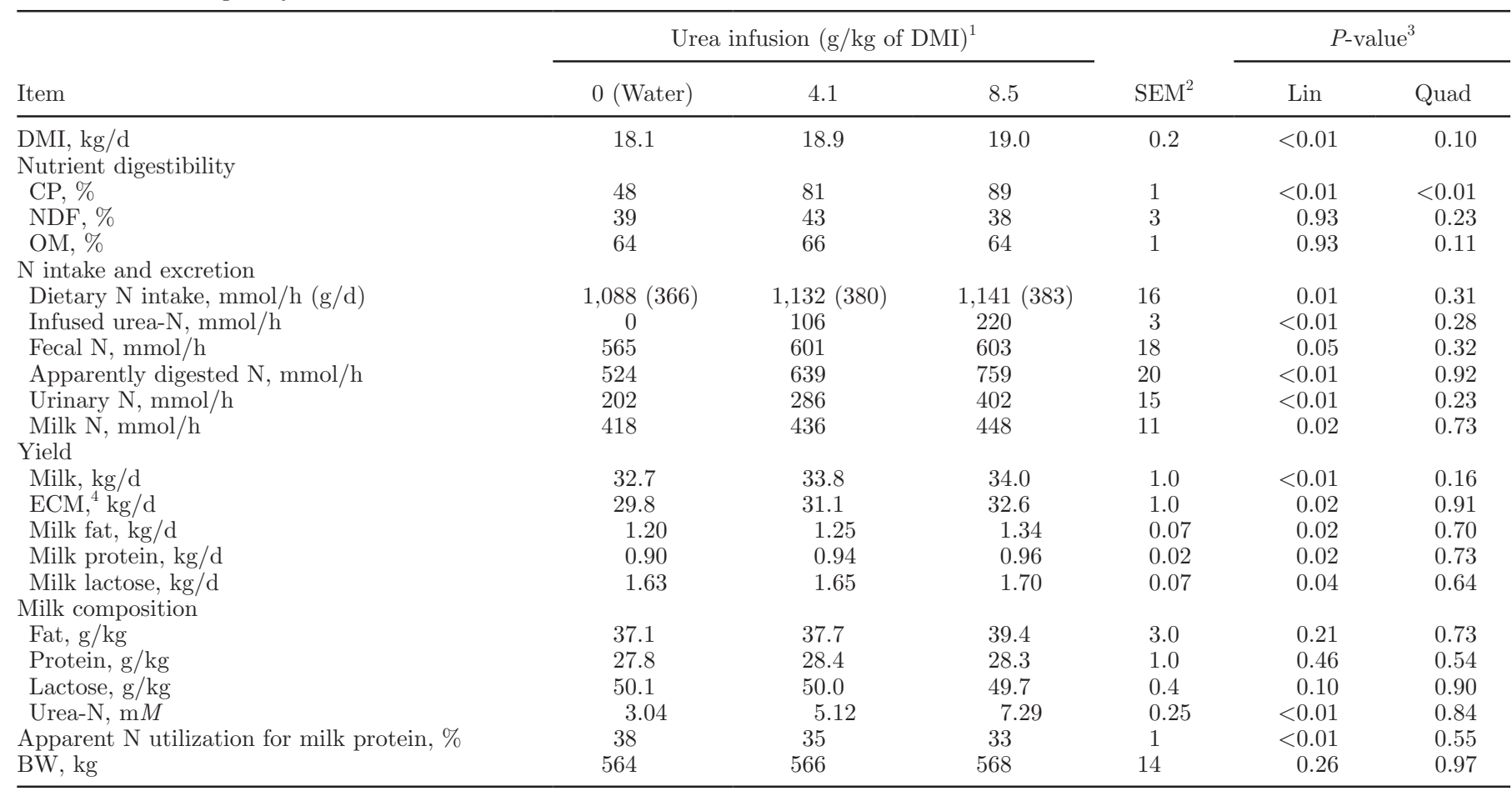

${ }^{1}$ Treatments were continuous ruminal infusion of water, $4.1 \mathrm{~g}$ of feed urea $/ \mathrm{kg}$ of DMI, and $8.5 \mathrm{~g}$ of feed urea $/ \mathrm{kg}$ of DMI.

${ }^{2} \mathrm{n}=8$, except for treatment $4.1 \mathrm{~g}$ of urea $/ \mathrm{kg}$ of DMI, where $\mathrm{n}=7$.

${ }^{3} P$-values for $\operatorname{Lin}=$ linear and Quad $=$ quadratic effects. Significance declared when $P \leq 0.05$, tendency when $P \leq 0.10$.

${ }^{4}$ Calculated according to Sjaunja et al. (1991).

\section{Arterial Variables}

Arterial pH, hematocrit, arterial blood concentrations of ammonia, oxygen, carbon dioxide, and arterial plasma concentrations of glucose, L-lactate, NEFA, and
BHBA were not affected by treatment (Table 4). A treatment by time interaction $(P=0.05)$ was observed for arterial blood concentration of ammonia; however, no meaningful interpretation of this interaction can be given. The arterial blood concentration of urea-N

Table 3. Effect of ruminal urea infusion on ruminal variables in lactating dairy cows ${ }^{1}$

\begin{tabular}{|c|c|c|c|c|c|c|c|c|}
\hline \multirow[b]{2}{*}{ Item } & \multicolumn{3}{|c|}{ Urea infusion $(\mathrm{g} / \mathrm{kg} \text { of DMI })^{2}$} & \multirow[b]{2}{*}{$\mathrm{SEM}^{3}$} & \multicolumn{4}{|c|}{$P$-value ${ }^{4}$} \\
\hline & 0 (Water) & 4.1 & 8.5 & & Lin & Quad & Time & Trt $\times$ time \\
\hline Ruminal pH & 6.63 & 6.57 & 6.56 & 0.036 & 0.05 & 0.50 & $<0.01$ & 0.14 \\
\hline Ammonia, mmol/L & 3.80 & 6.22 & 8.18 & 0.366 & $<0.01$ & 0.54 & $<0.01$ & 0.43 \\
\hline L-lactate, mmol/L & 1.69 & 2.05 & 1.88 & 0.330 & 0.67 & 0.52 & $<0.01$ & 0.44 \\
\hline Total VFA, mmol/L & 91 & 97 & 99 & 3.5 & $<0.01$ & 0.32 & $<0.01$ & 0.32 \\
\hline Acetate, $\mathrm{mol} / 100 \mathrm{~mol}$ & 62.0 & 62.0 & 61.6 & 0.46 & 0.48 & 0.70 & $<0.01$ & 0.44 \\
\hline Propionate, mol/100 mol & 21.0 & 21.3 & 21.5 & 0.49 & 0.27 & 0.89 & $<0.01$ & 0.62 \\
\hline Isobutyrate, mol/100 mol & 0.70 & 0.64 & 0.62 & 0.026 & $<0.01$ & 0.31 & $<0.01$ & 0.04 \\
\hline Butyrate, mol/100 mol & 12.9 & 12.8 & 12.8 & 0.39 & 0.89 & 0.86 & $<0.01$ & 0.76 \\
\hline Isovalerate, mol/100 mol & 1.3 & 1.2 & 1.3 & 0.07 & 0.68 & 0.48 & $<0.01$ & 0.03 \\
\hline Valerate, mol/100 mol & 1.5 & 1.4 & 1.5 & 0.04 & 0.94 & 0.46 & $<0.01$ & 0.66 \\
\hline Caproate, mol/100 mol & 0.77 & 0.73 & 0.74 & 0.034 & 0.48 & 0.63 & $<0.01$ & 0.40 \\
\hline
\end{tabular}

${ }^{1}$ Hourly samples (time) were collected during an 8-h period on d 14 of each experimental period.

${ }^{2}$ Treatments were continuous ruminal infusion of water, $4.1 \mathrm{~g}$ of feed urea $/ \mathrm{kg}$ of DMI, and $8.5 \mathrm{~g}$ of feed urea $/ \mathrm{kg}$ of DMI.

${ }^{3} \mathrm{n}=8$, except for treatment $4.1 \mathrm{~g}$ of urea/ $\mathrm{kg}$ of DMI, where $\mathrm{n}=7$.

${ }^{4} P$-values for Lin $=$ linear, Quad $=$ quadratic, time within sampling day $($ Time $)$, and treatment $($ Trt $) \times$ time interaction effects. Significance declared when $P \leq 0.05$, tendency when $P \leq 0.10$. 


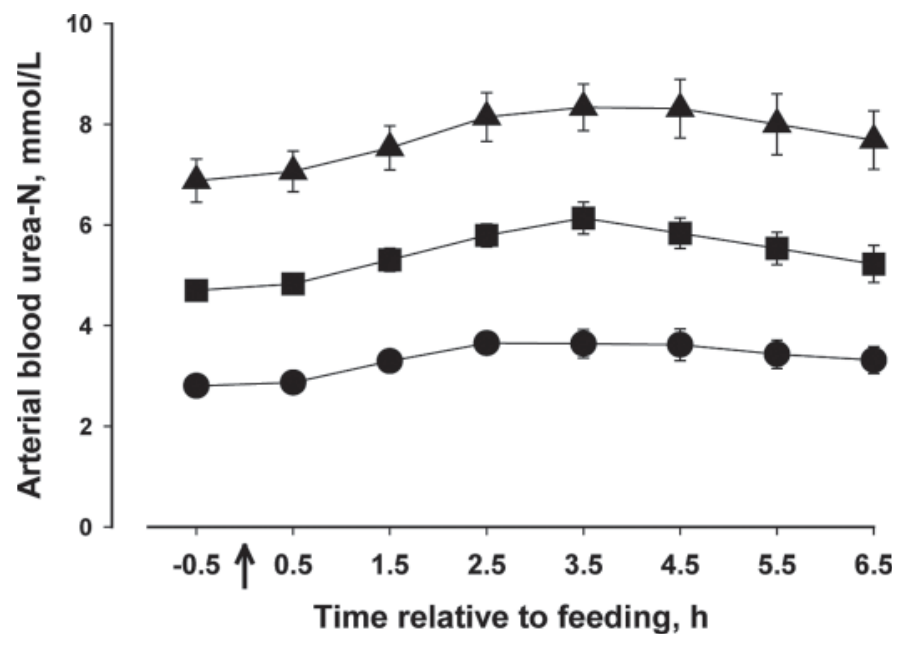

Figure 1. Arterial blood urea-N concentration (mmol/L) relative to time of feeding in lactating Holstein cows given continuous ruminal infusion of water (circles), $4.1 \mathrm{~g}$ (squares), and $8.5 \mathrm{~g}$ (triangles) of feed urea $/ \mathrm{kg}$ of DMI. The arrow indicates feeding time. Data points represent the means of 8 observations \pm standard error of the means, except for treatment $4.1 \mathrm{~g}$ of urea $/ \mathrm{kg}$ of DMI, where $\mathrm{n}=7$.

decreased linearly $(P<0.01$; Figure 1$)$ with decreasing urea infusion. The arterial plasma concentration of pAH increased linearly $(P=0.02)$ with decreasing urea infusion. A tendency $(P=0.06)$ for a quadratic effect on the arterial plasma concentration of NEFA was observed, reflecting an increased concentration with infusion of $4.1 \mathrm{~g}$ of urea $/ \mathrm{kg}$ of DMI compared with infusion of water and $8.5 \mathrm{~g}$ of urea $/ \mathrm{kg}$ of DMI. All arterial variables were affected $(P<0.01$ to $P=0.04)$ by time, except oxygen. For arterial concentrations of ammonia, urea-N, L-lactate, and BHBA the overall effects of time were a postprandial increase followed by a decrease to near prefeeding levels. For arterial concentrations of carbon dioxide and NEFA, the pattern was opposite. The concentration of arterial glucose increased $0.5 \mathrm{~h}$ after feeding but decreased at $1.5 \mathrm{~h}$ after feeding, reaching the nadir at $3.5 \mathrm{~h}$ after feeding. Arterial concentration of pAH appeared to increase slightly postprandially.

\section{Blood Flows and Net Fluxes}

The portal, hepatic, and hepatic arterial whole-blood flows were not affected by treatment (Table 5), but a postprandial increase in portal and hepatic whole-blood flows $(P=0.01$ and $P<0.01)$ was observed.

The net portal fluxes of urea-N, oxygen, carbon dioxide, glucose, BHBA, and L-lactate were not affected by treatment. The net portal flux of ammonia decreased linearly $(P<0.01)$ with decreasing urea infusion. The net portal flux of urea-N, carbon dioxide, glucose, and BHBA were not affected by time. The net portal flux of ammonia increased $(P<0.01)$ after feeding. The net portal flux of oxygen, and L-lactate tended $(P=$ 0.07 ) to be affected by time, but no obvious pattern was observed.

Net hepatic urea-N release and net hepatic ammonia uptake decreased linearly $(P<0.01)$ with decreasing urea infusion. Hepatic ammonia uptake accounted for 97,87 , and $95 \pm 5 \%$ of net hepatic urea-N release with water infusion, 4.1 , and $8.5 \mathrm{~g}$ of urea $/ \mathrm{kg}$ of DMI, respectively, and was not affected (data not shown) by treatment. A tendency for a treatment by time interaction $(P=0.08)$ for net hepatic flux of urea-N was observed, which indicates a tendency for a larger

Table 4. Effect of ruminal urea infusion on arterial variables in lactating dairy cows ${ }^{1}$

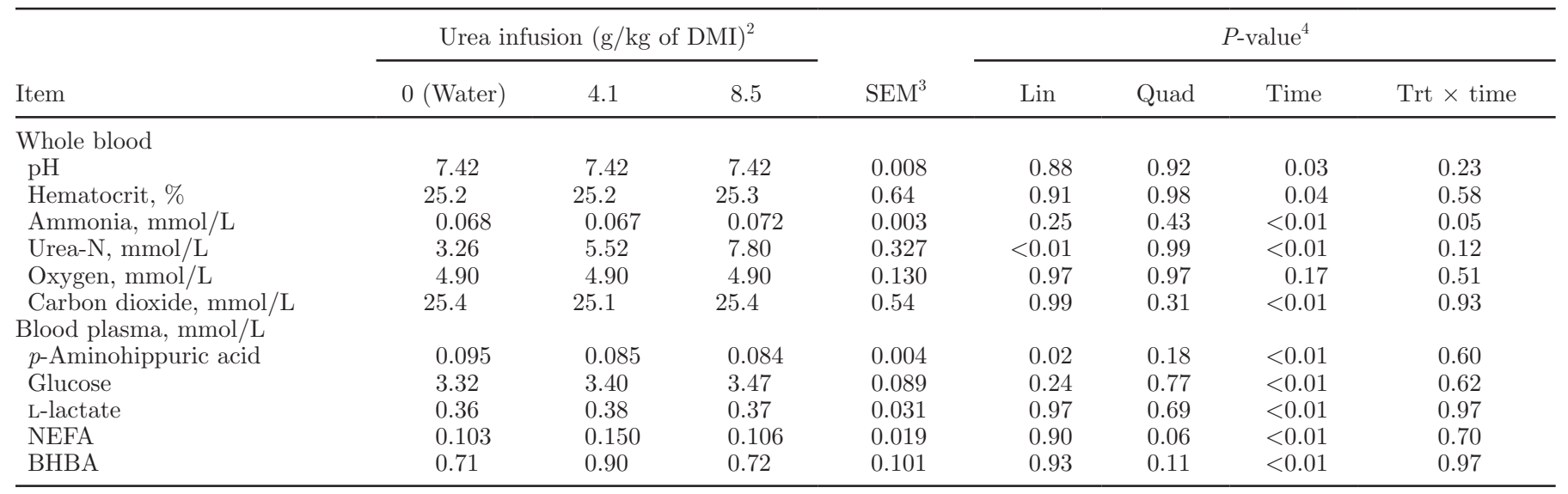

${ }^{1}$ Hourly samples (time) were collected during an 8-h period on d 14 of each experimental period.

${ }^{2}$ Treatments were continuous ruminal infusion of water, $4.1 \mathrm{~g}$ of feed urea $/ \mathrm{kg}$ of DMI, and $8.5 \mathrm{~g}$ of feed urea $/ \mathrm{kg}$ of DMI.

${ }^{3} \mathrm{n}=8$, except for treatment $4.1 \mathrm{~g}$ of urea $/ \mathrm{kg}$ of DMI, where $\mathrm{n}=7$.

${ }^{4} P$-values for Lin $=$ linear, Quad $=$ quadratic, time within sampling day (Time), and treatment $($ Trt $) \times$ time interaction effects. Significance declared when $P \leq 0.05$, tendency when $P \leq 0.10$. 
postprandial increase in hepatic release of urea- $\mathrm{N}$ with water infusion compared with 4.1 and $8.5 \mathrm{~g}$ of urea $/ \mathrm{kg}$ of DMI. The net hepatic fluxes of oxygen, carbon dioxide, glucose, BHBA, and L-lactate were not affected by treatment. However, a tendency for a treatment by time interaction $(P=0.08)$ for net hepatic flux of L-lactate was observed; however, this interaction was difficult to interpret. The net hepatic fluxes of urea$\mathrm{N}$, ammonia, oxygen, and BHBA were affected $(P<$ 0.01 to $P=0.03)$ by time, whereas net hepatic flux of carbon dioxide tended to be affected $(P=0.06)$ by time, all reflecting a postprandial increase, followed by a decrease toward prefeeding levels. Net hepatic fluxes of glucose and L-lactate were not affected by time.

The net splanchnic fluxes of measured variables were not affected by treatment, except for net splanchnic blood flux of urea-N, which decreased $(P<0.01)$ with decreasing urea infusion. The net splanchnic blood flux of ammonia averaged $-0.3 \pm 15 \mathrm{mmol} / \mathrm{h}$, reflecting that the net portal release of ammonia was completely removed by the liver. A tendency for a treatment by time interaction $(P=0.09)$ for net splanchnic flux of glucose was observed; however, no meaningful interpretation could be given. The net splanchnic flux of

Table 5. Effect of ruminal urea infusion on blood flows, net fluxes of metabolites, and portal-drained viscera (PDV), and ruminal extraction ratio of arterial urea- $\mathrm{N}$ in lactating dairy cows $^{1}$

\begin{tabular}{|c|c|c|c|c|c|c|c|c|}
\hline Item & \multicolumn{3}{|c|}{ Urea infusion $(\mathrm{g} / \mathrm{kg} \text { of } \mathrm{DMI})^{2}$} & $\mathrm{SEM}^{3}$ & \multicolumn{4}{|c|}{$P$-value ${ }^{4}$} \\
\hline \multicolumn{9}{|l|}{ Whole blood flows, $\mathrm{L} / \mathrm{h}$} \\
\hline Hepatic vein & 1,877 & 1,822 & 1,824 & 56 & 0.48 & 0.68 & $<0.01$ & 0.14 \\
\hline Hepatic artery & 242 & 210 & 271 & 29 & 0.40 & 0.15 & 0.14 & 0.69 \\
\hline \multicolumn{9}{|l|}{ Net portal blood flux, $\mathrm{mmol} / \mathrm{h}$} \\
\hline Carbon dioxide & 1,579 & 1,579 & 1,698 & 202 & 0.49 & 0.70 & 0.21 & 0.49 \\
\hline \multicolumn{9}{|l|}{ Net portal plasma flux, $\mathrm{mmol} / \mathrm{h}$} \\
\hline Glucose & -15 & 17 & 6 & 19 & 0.42 & 0.34 & 0.73 & 0.79 \\
\hline BHBA & 174 & 166 & 176 & 15 & 0.92 & 0.58 & 0.26 & 0.86 \\
\hline L-lactate & 126 & 125 & 126 & 10 & 0.97 & 0.92 & 0.07 & 0.11 \\
\hline \multicolumn{9}{|l|}{ Net hepatic blood flux, $\mathrm{mmol} / \mathrm{h}$} \\
\hline Glucose & 573 & 589 & 584 & 32 & 0.74 & 0.73 & 0.86 & 0.34 \\
\hline BHBA & 222 & 227 & 202 & 29 & 0.54 & 0.63 & 0.02 & 0.76 \\
\hline L-lactate & -190 & -196 & -178 & 19 & 0.50 & 0.48 & 0.24 & 0.08 \\
\hline \multicolumn{9}{|l|}{ Net splanchnic blood flux, $\mathrm{mmol} / \mathrm{h}$} \\
\hline Urea-N & 120 & 192 & 263 & 32 & $<0.01$ & 0.76 & 0.02 & 0.60 \\
\hline Ammonia & 1.7 & -1.3 & -1.3 & 2.1 & 0.21 & 0.51 & $<0.01$ & 0.26 \\
\hline Oxygen & $-3,962$ & $-3,912$ & $-4,049$ & 125 & 0.59 & 0.53 & $<0.01$ & 0.36 \\
\hline Carbon dioxide & 2,598 & 2,647 & 2,771 & 229 & 0.49 & 0.87 & 0.14 & 0.33 \\
\hline \multicolumn{9}{|l|}{ Net splanchnic plasma flux, mmol/h } \\
\hline Glucose & 562 & 602 & 591 & 28 & 0.40 & 0.42 & 0.24 & 0.09 \\
\hline BHBA & 398 & 393 & 377 & 29 & 0.59 & 0.88 & $<0.01$ & 0.51 \\
\hline L-lactate & -63 & -73 & -54 & 13 & 0.57 & 0.34 & 0.12 & 0.81 \\
\hline \multicolumn{9}{|l|}{ Extraction of arterial urea-N } \\
\hline PDV,$\%$ & 4.32 & 3.65 & 2.46 & 0.31 & $<0.01$ & 0.37 & $<0.01$ & 0.22 \\
\hline
\end{tabular}

${ }^{1}$ Hourly samples (time) were collected during an 8-h period on d 14 of each experimental period.

${ }^{2}$ Treatments were continuous ruminal infusion of water, $4.1 \mathrm{~g}$ of feed urea $/ \mathrm{kg}$ of DMI, and $8.5 \mathrm{~g}$ of feed urea $/ \mathrm{kg}$ of DMI.

${ }^{3} \mathrm{n}=8$, except for treatment $4.1 \mathrm{~g}$ of urea $/ \mathrm{kg}$ of DMI, where $\mathrm{n}=7$. For ruminal uptake of arterial urea-N, $\mathrm{n}=6$, except for treatment $0 \mathrm{~g}$ and $4.1 \mathrm{~g}$ of urea $/ \mathrm{kg}$ of DMI, where $\mathrm{n}=5$.

${ }^{4} P$-values for Lin $=$ linear, Quad $=$ quadratic, time within sampling day $($ Time $)$, and treatment $($ Trt $) \times$ time interaction effects. Significance declared when $P \leq 0.05$, tendency when $P \leq 0.10$.

${ }^{5} \mathrm{UT}-\mathrm{B}=$ urea transporter $\mathrm{B} ; \Delta \mathrm{Ct}=\mathrm{Ct}$ of the target gene $-\mathrm{Ct}$ of the housekeeping gene $(\mathrm{Ct}=$ the number of PCR cycles required to reach a certain threshold; Theil et al., 2006). 


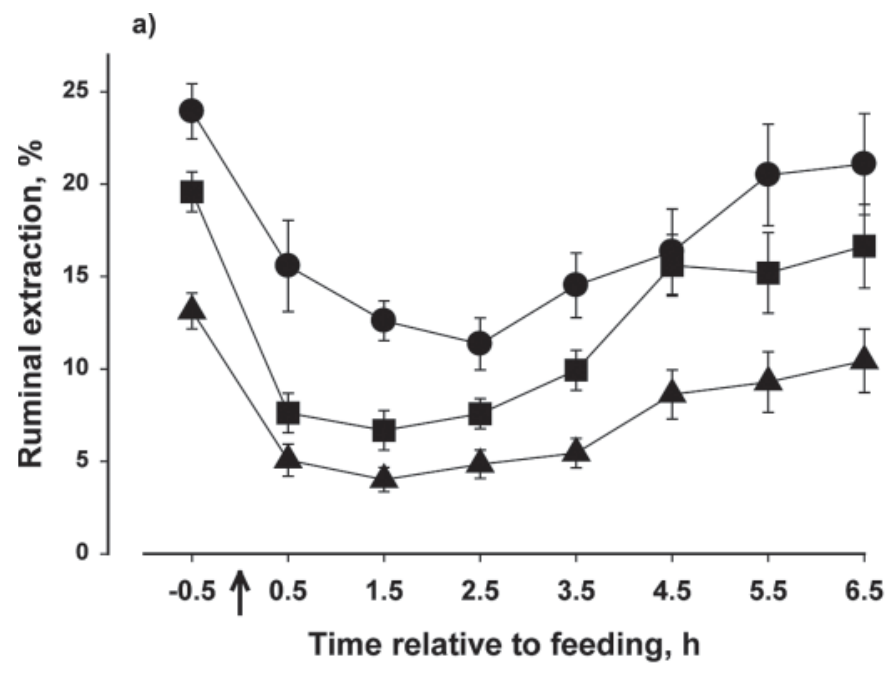

b)

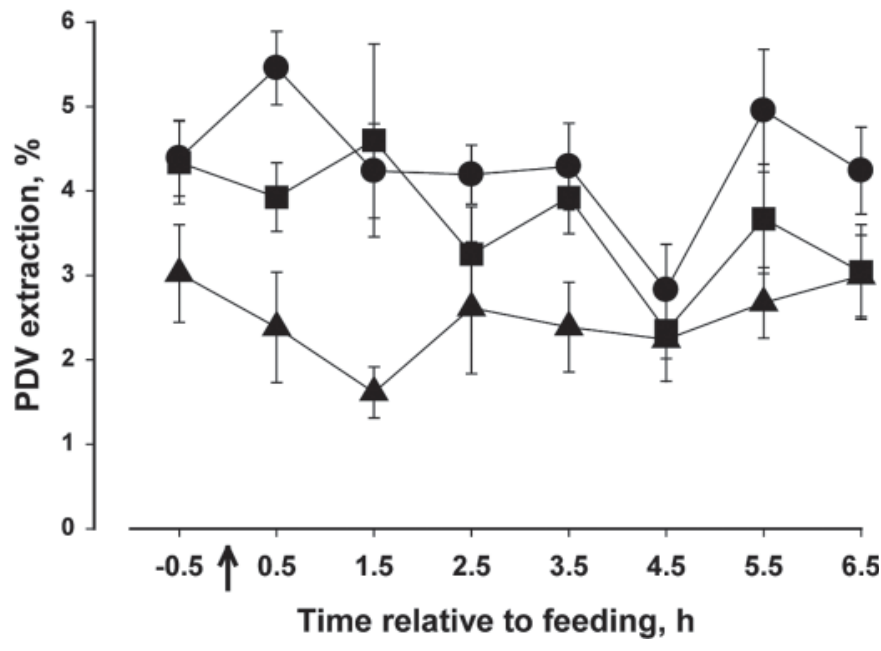

Figure 2. Ruminal extraction (a) and portal-drained visceral (PDV) extraction (b) of arterial urea-N (\%) relative to time of feeding in lactating Holstein cows given continuous ruminal infusion of water (circles), $4.1 \mathrm{~g}$ (squares), and $8.5 \mathrm{~g}$ (triangles) of feed urea $/ \mathrm{kg}$ of DMI. The arrow indicates feeding time. For ruminal extraction of arterial urea- $\mathrm{N}$, the data points represent the means of 6 observations \pm standard error of the means, except for treatment $4.1 \mathrm{~g}$ of urea $/ \mathrm{kg}$ of DMI, where $\mathrm{n}=5$. For PDV extraction of arterial urea-N, the data points represent the means of 8 observations \pm standard error of the means, except for treatment $8.5 \mathrm{~g}$ of urea/ $\mathrm{kg}$ of DMI, where $\mathrm{n}=7$.

urea-N, ammonia, oxygen, and BHBA were affected $(P$ $<0.01$ to $P=0.02$ ) by time, reflecting a postprandial increase, followed by a decrease toward prefeeding levels. Net splanchnic fluxes of carbon dioxide, glucose, and L-lactate were not affected by time.

\section{PDV and Ruminal Extraction of Arterial Urea-N}

The extraction ratios of arterial urea-N by the PDV and ruminal wall increased linearly $(P<0.01$; Table
5) with decreasing urea infusion. Both PDV and ruminal extractions of arterial urea-N were affected by time $(P<0.01)$. Ruminal extraction of arterial urea$\mathrm{N}$ decreased after feeding (Figure 2a). The nadir was observed 1.5 to $2.5 \mathrm{~h}$ after feeding; hereafter, extraction increased toward the prefeeding level. Portal-drained visceral extraction of arterial urea-N was less affected by time relative to feeding (Figure $2 \mathrm{~b}$ ). The abundance of UT-B mRNA in ruminal papillae was not affected $(P=0.11)$ by urea infusion; however, numerically, the UT-B mRNA abundance was lower with infusion of 4.1 and $8.5 \mathrm{~g}$ of urea $/ \mathrm{kg}$ of DMI, respectively, compared with water infusion. The abundance of UT-B mRNA was affected $(P<0.01$, data not shown $)$ by period, reflecting a lower UT-B mRNA abundance in the third period when compared with the first period.

\section{Renal Variables}

Urinary $\mathrm{pH}$, urine concentration of creatinine- $\mathrm{N}$, diuresis, and creatinine- $\mathrm{N}$ clearance were not affected by treatment (Table 6). Decreasing ruminal urea infusion linearly decreased $(P<0.01)$ urinary urea-N clearance, and filtered load of urea-N, whereas urea-N reabsorbed by the kidney increased $(P<0.01)$ linearly. Plasma concentration of creatinine- $\mathrm{N}$ tended $(P=0.09)$ to increase, whereas renal plasma flow tended $(P=0.10)$ to decrease with decreasing urea infusion. The urinary excretion of total $\mathrm{N}$, urea- $\mathrm{N}$, and AA-N decreased linearly $(P<0.01)$ with decreasing urea infusion, whereas excretion rates of hippuric acid, allantoin- $\mathrm{N}$, creatinine$\mathrm{N}$, and uric acid- $\mathrm{N}$ in urine were not affected by treatment. The proportion of total urine $\mathrm{N}$ not accounted for in specific urinary metabolites (37 to $53 \pm 11 \%$ ) was not affected by treatment. All renal variables were affected by time $(P<0.01$ to $P=0.04)$ except for urinary $\mathrm{pH}$ and creatinine- $\mathrm{N}$ clearance. Arterial plasma concentration of creatinine- $\mathrm{N}$ was relatively stable during sampling times but decreased from 6.5 to $7.5 \mathrm{~h}$ after feeding, whereas urinary creatinine- $\mathrm{N}$ excretion increased postprandially, followed by a decrease toward prefeeding level. Renal plasma flow decreased slightly after feeding. Diuresis was relatively stable throughout the sampling window, except from being less 0.5 $\mathrm{h}$ before to $0.5 \mathrm{~h}$ after feeding compared with later sampling times. Urea- $\mathrm{N}$ clearance decreased postprandially, followed by an increase toward prefeeding level. The filtered load of urea-N changed little with time. Urinary urea- $\mathrm{N}$ excretion decreased immediately after feeding, most pronounced for $8.5 \mathrm{~g}$ of urea $/ \mathrm{kg}$ of DMI (treatment by time, $P=0.02$ ), increasing to prefeeding levels during the sampling window. The effect of time on hippuric acid, creatinine- $\mathrm{N}$, and AA-N excretion rates in urine was reflected by a small postprandial in- 
Table 6. Effect of ruminal urea infusion on renal variables in lactating dairy cows ${ }^{1}$

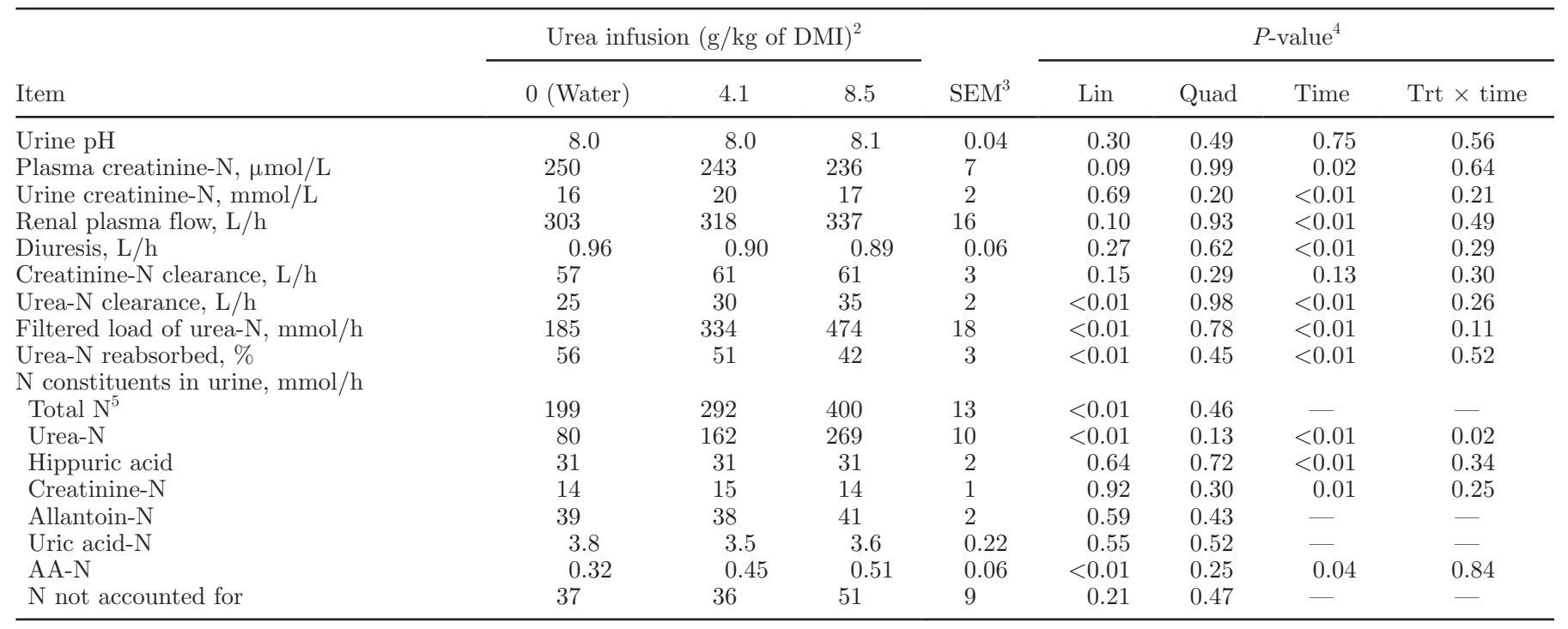

${ }^{1}$ Hourly samples (time) were collected during an 8-h period on d 14 of each experimental period.

${ }^{2}$ Treatments were continuous ruminal infusion of water, $4.1 \mathrm{~g}$ of feed urea $/ \mathrm{kg}$ of DMI, and $8.5 \mathrm{~g}$ of feed urea $/ \mathrm{kg}$ of DMI.

${ }^{3} \mathrm{n}=8$, except for treatment $4.1 \mathrm{~g}$ of urea $/ \mathrm{kg}$ of DMI, where $\mathrm{n}=7$.

${ }^{4} P$-values for Lin $=$ linear, Quad $=$ quadratic, time within sampling day $($ Time $)$, and treatment $($ Trt $) \times$ time interaction effects. Significance declared when $P \leq 0.05$, tendency when $P \leq 0.10$.

${ }^{5}$ Total $\mathrm{N}$ in urine has been corrected for $p$-aminohippuric acid (pAH).

crease in rate of excretion, followed by decrease toward prefeeding level.

\section{DISCUSSION}

The basal diet (water infusion treatment) was designed to provide a content of RDP well below the minimum recommendations for dairy cows (Madsen et al., 1995). The 3 experimental treatments were either highly deficient (water infusion), marginally deficient (4.1 $\mathrm{g}$ of urea $/ \mathrm{kg}$ of DMI), or near the recommended requirement for $\mathrm{RDP}$ ( $8.5 \mathrm{~g}$ of urea $/ \mathrm{kg}$ of $\mathrm{DMI})$. Decreasing urea infusion decreased both DMI and milk yield, demonstrating that cows were challenged by the low- $\mathrm{N}$ supply. These observations are in line with the general observed effects of decreasing dietary $\mathrm{N}$ intake on DMI responses in cattle (Broderick, 2003; Klevesahl et al., 2003).

\section{Ammonia and VFA}

The observed ruminal ammonia concentrations with infusion of water and $4.1 \mathrm{~g}$ of urea $/ \mathrm{kg}$ of DMI fell during long periods of the day below the commonly used estimate of $3.6 \mathrm{mmol} / \mathrm{L}$ obtained in vitro for maximizing microbial growth (Satter and Slyter, 1974). With infusion of $8.5 \mathrm{~g}$ of urea $/ \mathrm{kg}$ of DMI, the ruminal ammonia concentration was above $3.6 \mathrm{mmol} / \mathrm{L}$ during the entire feeding cycle. The observed ruminal ammonia concentrations below the classic estimate needed to maximize microbial activity with infusion of water and $4.1 \mathrm{~g}$ of urea $/ \mathrm{kg}$ of DMI agrees with these treatments being designed to be below the requirement for RDP and also indicates that cows were unable to decrease ammonia absorption from the rumen when supplied deficiently with $\mathrm{N}$.

Decreasing N supply decreased ruminal VFA concentrations, but had only marginal effects on VFA composition. Because no effects were observed on NDF and OM digestibilities, and VFA concentrations appeared closely related to feed intake, it can be speculated that the combination of feed restriction and different intakes between treatments might have resulted in this relatively strong response in total VFA concentration to treatments.

\section{Urea-N Recycling}

Cattle are capable of transferring an increasing proportion of hepatic urea-N to the GI tract with decreasing N status (Wickersham et al., 2008) and thereby seem to possess a mechanism of salvaging $\mathrm{N}$ and directing urea- $\mathrm{N}$ to the rumen when $\mathrm{N}$ intake limits ruminal fermentation. Surprisingly, several studies have shown that recycling in absolute amounts does not increase with decreasing $\mathrm{N}$ status in dairy heifers and 
cows (Marini and Van Amburgh, 2003; Calsamiglia et al., 2010). In the present study, where DMI and milk yield were shown to be limited by RDP supply, the net portal blood flux of urea- $\mathrm{N}$ was not different between diets (i.e., the cows did not meet the RDP challenge by increasing the absolute urea- $\mathrm{N}$ transport to the GI tract). This shows that the regulatory response of the cows either is only partly effective or controlled by something else than the ammonia requirements of ruminal fermentation.

The site of urea-N entry to the GI tract is of importance because conversion of recycled urea- $\mathrm{N}$ into microbial protein and subsequent AA absorption can occur only when urea- $\mathrm{N}$ is recycled to the rumen. In the present study, with the lowest $\mathrm{N}$ supply (water infusion), the ruminal extraction of arterial urea- $\mathrm{N}$ was upregulated approximately 3.9 fold compared with the PDV extraction, in line with Kristensen et al. (2010) who observed a 2.9-fold increase between ruminal and PDV extraction of arterial urea-N. This indicates differential regulation with specific upregulation of ruminal extraction of arterial urea- $\mathrm{N}$ compared with a relatively constant urea-N extraction by the post-ruminal tissues (Siddons et al., 1985; Kristensen et al., 2010) and in that way, favoring recycling to the rumen compared with the post-ruminal compartments. One possible explanation for the observed upregulation of urea- $\mathrm{N}$ transport with low- $\mathrm{N}$ diets could be by increased blood flow because only blood passing the epithelia supplies urea- $\mathrm{N}$ to the GI tract. However, when tested under washed rumen conditions, feeding lactating dairy cows a high or low-N diet did not indicate fundamental changes in epithelial blood flow [A. C. Storm (Department of Animal Health and Bioscience, Aarhus University, Tjele, Denmark), M. D. Hanigan (Department of Dairy Science, Virginia Polytechnic Institute and State University, Blacksburg), and N. B. Kristensen, unpublished data).

Urea-N transport across gut epithelia of ruminants has been shown to be regulated by mass action and adaptive changes in epithelial permeability of urea- $\mathrm{N}$ (Houpt, 1970; Kristensen et al., 2010). In dairy cattle adapted to low- or high- $\mathrm{N}$ intake, the rumen wall extraction ratio of arterial urea- $\mathrm{N}$ was not affected by intravenous urea infusion, which indicates that the activity of urea transporters was unaffected by short-term variation in urea- $\mathrm{N}$ concentration and epithelial urea-N transport (Kristensen et al., 2010). The present study showed in full agreement with the previous study that adaptation of epithelial urea- $\mathrm{N}$ extraction responded to $\mathrm{N}$ supply and it was shown that the response was linear in the range of $\mathrm{N}$ supply studied. However, it was apparent from the postprandial decrease in ruminal urea- $\mathrm{N}$ extraction from arterial blood that a short-term regulatory mechanism affecting ruminal urea- $\mathrm{N}$ handling oc- curred, not identified in previous studies manipulating urea-N concentrations in ruminal buffers or blood. This mechanism canceled the effect of postprandial increases in both arterial urea- $\mathrm{N}$ concentration and portal blood flow on urea-N transport. If urea-N transport had been regulated solely by mass action, a postprandial increase in PDV uptake should have been observed. It can be speculated that the postprandial increase in ruminal ammonia concentration affects the ruminal extraction of arterial urea- $\mathrm{N}$ on a relatively short-term basis, leading to decreases in extraction ratio in the first hours after feeding. This hypothesis suggests a more complicated regulatory mechanism for urea- $\mathrm{N}$ transport than suggested by simple mass action. Previous studies have shown that plasma urea- $\mathrm{N}$ concentration above 8 to $10 \mathrm{mM}$ can be inhibitory to urea- $\mathrm{N}$ transport fluid (Harmeyer and Martens, 1980; Sunny et al., 2007). This effect seems not related to urea- $\mathrm{N}$ concentration per se (see above), but might be an indirect effect of hydrolysis of recycled urea-N leading to an increased ammonia concentration in the rumen epithelium and rumen fluid (Harmeyer and Martens, 1980; Sunny et al., 2007).

\section{Urea Transporters}

From studies mainly on rodents it is well established that facilitative urea transporter (UT-A and UT-B) proteins in the kidneys play a role in the urinary concentrating mechanism and are partly responsible for the transport of urea- $\mathrm{N}$ in the renal medulla, and that they are also involved in the salvage of urea- $\mathrm{N}$ from excretion under conditions of low-N supply (Sands, 1999). In rats fed low-N diets, Isozaki et al. (1994) observed an increased reabsorption of urea- $\mathrm{N}$ in the inner medullary collecting duct, indicative of activation or increase in expression of the urea transporter (UT) protein. The finding of UT-B protein being expressed in the GI tract of ruminants (Ritzhaupt et al., 1998; Marini and Van Amburgh, 2003; Stewart et al., 2005) has attracted attention to these transporters in explaining changes in urea- $\mathrm{N}$ permeability of rumen epithelium under changing dietary conditions. It has been shown that UT-B expression correlates with dietary energy intake (Simmons et al., 2009). Data from transition cows (Røjen et al., 2008b) showed that UT-B mRNA abundance postpartum was less than half compared with that prepartum. In support of the latter, in the present study, the abundance of UT-B mRNA was affected by period, reflecting UT-B mRNA abundance decreasing with DIM. Still the role of UT-B in urea-N salvaging in ruminants remains equivocal. In the present study, no effect of decreasing N supply on the UT-B mRNA abundance in ruminal papillae was observed. 
Still, changes in UT-B mRNA abundance alone may not be a good indicator of changes in UT-B protein expression (Ludden et al., 2009). In the present study, the UT-B mRNA abundance only explains a minor proportion of the total variability in the urea- $\mathrm{N}$ transport across the ruminal wall $\left(\mathrm{R}^{2}=0.32\right)$. A similar finding occurred in the study of Røjen et al. (2008b) when only postpartum data was considered $\left(\mathrm{R}^{2}=0.50\right)$. In addition to UT-B, the regulatory mechanism related to permeability of urea- $\mathrm{N}$ across the gut epithelia may also involve aquaporins (Litman et al., 2009) and urea permease toxins secreted by epithelial microbes (Stewart and Smith, 2005). These toxins might act as a urea permease directly on the epithelium and thereby increase the movement of urea- $\mathrm{N}$ into the gut lumen and primarily promote the growth of the epithelial population of microbes (Stewart and Smith, 2005).

\section{Renal Urea-N Kinetics}

Consistent with the changes in the filtered load of urea-N reported in the literature (Cirio and Boivin, 1990; Marini and Van Amburgh, 2003; Tebot et al., 2002), this study showed a decreased filtered load of urea-N with decreasing urea infusion caused by the decreased blood urea-N level and a decreased renal plasma flow. The observed decrease in renal urea- $\mathrm{N}$ clearance as well as the increase in the reabsorption of urea- $\mathrm{N}$ filtered by the kidneys with decreasing urea infusion, indicate that the kidneys were salvaging urea- $\mathrm{N}$ from excretion and, thereby, increased urea-N available for recycling to the GI tract. This increase in urea-N reabsorption with low-N diets is consistent with the increase in urea transporter protein expression observed in rats (Terris et al., 1998; Sands, 1999).

The distribution of non-urea-N components in urine corresponds with the findings by Bristow et al. (1992). In the present study, the rate of excretion of urinary non-urea- $\mathrm{N}$ components was not affected by decreasing urea infusion, except for a small decrease in AA-N excretion. Excretion of nitrogenous constituents other than urea- $\mathrm{N}$ will influence the overall $\mathrm{N}$ efficiency of the cow more at low than at high-N intakes (urea-N was $67 \%$ of urine $\mathrm{N}$ with $8.5 \mathrm{~g}$ of urea $/ \mathrm{kg}$ of DMI and $40 \%$ with water). To increase the $\mathrm{N}$ efficiency of dairy cows fed at low- $\mathrm{N}$ intakes, factors such as absorption and endogenous production of benzoic acid, intake of ruminal bypass protein, and microbial sequestration of intestinal absorption of purines and pyrimidines will be of increasing importance.

\section{CONCLUSIONS}

Urea-N recycling to the gastrointestinal tract of lactating dairy cows did not increase in response to decreasing supply with RDP. We observed that cows responded with increasing feed intake and milk production to increased ruminal urea infusion when fed a low-RDP diet and that recycling had no potential for compensating low-RDP diets when cows were fed diets with $\mathrm{N}$ concentrations equivalent to 12 to $16 \%$ of dietary CP. Decreasing N supply increased the extraction of arterial urea-N across the rumen and the PDV with an overall shift toward the rumen. The adaptation of epithelial urea-N extraction with decreasing $\mathrm{N}$ supply compensated for the decreasing arterial concentration of urea-N, thus resulting in a relatively constant transport of urea across treatments. We observed a short-term regulation of ruminal extraction of arterial urea- $\mathrm{N}$, preventing a postprandial increase in urea- $\mathrm{N}$ transport across the rumen wall. It was not possible to correlate UT-B mRNA abundance with changes in N supply.

\section{ACKNOWLEDGMENTS}

We gratefully acknowledge Birgit H. Løth, Anne Krustrup, Ole H. Olsen, Thorkild N. Jakobsen, Kasper B. Poulsen, Anne-Mette Edith Olsen, Inger Østergaard, and the barn staff at Faculty of Agricultural Sciences, Aarhus University, Tjele, Denmark for skillful technical assistance. B. A. Røjen held a $\mathrm{PhD}$ scholarship cofinanced by the Faculty of Life Sciences, University of Copenhagen, Frederiksberg C, Denmark (Department of Basic Animal and Veterinary Sciences) and the Faculty of Agricultural Sciences, Aarhus University, Tjele, Denmark. Funding for the study was provided by the Commission of the European Communities (Brussels, Belgium; FP7, KBBE-2007-1), the Directorate for Food, Fisheries, and Agri Business (Copenhagen, Denmark; \#3304-VMP-05-005), and the Danish Ministry of Food, Agriculture, and Fisheries, Copenhagen, Denmark.

\section{REFERENCES}

Børsting, C. F., T. Kristensen, L. Misciattelli, T. Hvelplund, and M. R. Weisbjerg. 2003. Reducing nitrogen surplus from dairy farms. Effects of feeding and management. Livest. Prod. Sci. 83:165-178.

Bristow, A. W., D. C. Whitehead, and J. E. Cockburn. 1992. Nitrogenous constituents in the urine of cattle, sheep and goats. J. Sci. Food Agric. 59:387-394.

Broderick, G. A. 2003. Effects of varying dietary protein and energy levels on the production of lactating dairy cows. J. Dairy Sci. 86:1370-1381.

Calsamiglia, S., A. Ferret, C. K. Reynolds, N. B. Kristensen, and A. M. van Vuuren. 2010. Strategies for optimizing nitrogen use by ruminants. Animal 4:1184-1196.

Cirio, A., and R. Boivin. 1990. Urea recycling from the renal pelvis in sheep: A study with [14C]urea. Am. J. Physiol. 258:F1196F1202.

Hansen, B. 1989. Determination of nitrogen as elementary N, an alternative to Kjeldahl. Acta Agric. Scand. 39:113-118.

Harmeyer, J., and H. Martens. 1980. Aspects of urea metabolism in ruminants with reference to the goat. J. Dairy Sci. 63:1707-1728.

Houpt, T. R. 1970. Transfer of urea and ammonia to the rumen. Pages 119-131 in Physiology of Digestion and Metabolism in the Ru- 
minant. A. T. Phillipson, ed. Oriel Press Ltd., Newcastle upon Tyne, UK.

Huhtanen, P., and A. N. Hristov. 2009. A meta-analysis of the effects of dietary protein concentration and degradability on milk protein yield and milk $\mathrm{N}$ efficiency in dairy cows. J. Dairy Sci. 92:3222-3232.

Isozaki, T., A. G. Gillin, C. E. Swanson, and J. M. Sands. 1994. Protein restriction sequentially induces new urea transport processes in rat initial IMCD. Am. J. Physiol. 266:F756-F761.

Katz, M. L., and E. N. Bergman. 1969. Simultaneous measurements of hepatic and portal venous blood in flow in the sheep and dog. Am. J. Physiol. 216:946-952.

Klevesahl, E. A., R. C. Cochran, E. C. Titgemeyer, T. A. Wickersham, C. G. Farmer, J. I. Arroquy, and D. E. Johnson. 2003. Effect of a wide range in the ratio of supplemental rumen degradable protein to starch on utilization of low-quality, grass hay by beef steers. Anim. Feed Sci. Technol. 105:5-20.

Kristensen, N. B. 2000. Quantification of whole blood short-chain fatty acids by gas chromatographic determination of plasma 2-chloroethyl derivatives and correction for dilution space in erythrocytes. Acta Agric. Scand. A Anim. Sci. 50:231-236

Kristensen, N. B., A. Danfær, V. Tetens, and N. Agergaard. 1996. Portal recovery of intraruminally infused short-chain fatty acids in sheep. Acta Agric. Scand. A Anim. Sci. 46:26-38.

Kristensen, N. B., J. V. Nørgaard, S. Wamberg, M. Engbæk, J. A Fernández, H. D. Zacho, and H. D. Poulsen. 2009b. Absorption and metabolism of benzoic acid in growing pigs. J. Anim. Sci. $87: 2815-2822$.

Kristensen, N. B., B. A. Røjen, B. M. L. Raun, A. C. Storm, L. Puggaard, and M. Larsen. 2009a. Hepatic acetylation of the blood flow marker $p$-aminohippuric affect measurement of hepatic blood flow in cattle. Pages 558-559 in XIth International Symposium on Ruminant Physiology, Clermont-Ferrand, France. Y. Chilliard, F. Glasser, Y. Faulconnier, F. Bocquier, I. Veissier, and M. Doreau, ed. Wageningen Academic Publishers, Wageningen, the Netherlands.

Kristensen, N. B., A. C. Storm, and M. Larsen. 2010. Effect of dietary nitrogen content and intravenous urea infusion on ruminal and portal-drained visceral extraction of arterial urea in lactating Holstein cows. J. Dairy Sci. 93:2670-2683.

Lapierre, H., and G. E. Lobley. 2001. Nitrogen recycling in the ruminant: A review. J. Dairy Sci. 84:E223-E236.

Larsen, M., and N. B. Kristensen. 2009. Effect of abomasal glucose infusion on splanchnic amino acid metabolism in periparturient dairy cows. J. Dairy Sci. 92:3306-3318.

Litman, T., R. Søgaard, and T. Zeuthen. 2009. Ammonia and urea permeability of mammalian aquaporins. Handb. Exp. Pharmacol. 190:327-358

Lobley, G. E., X. Shen, G. Le, D. M. Bremner, E. Milne, A. G. Calder, S. E. Anderson, and N. Dennison. 2003. Oxidation of essential amino acids by the ovine gastrointestinal tract. Br. J. Nutr. 89:617-629.

Ludden, P. A., R. M. Stohrer, K. J. Austin, R. L. Atkinson, E. L. Belden, and H. J. Harlow. 2009. Effect of protein supplementation on expression and distribution of urea transporter-B in lambs fed low-quality forage. J. Anim. Sci. 87:1354-1365.

Madsen, J., T. Hvelplund, M. R. Weisbjerg, J. Bertilsson, I. Olsson, R. Spörndly, O. M. Harstad, H. Volden, M. Tuori, T. Varvikko, P. Huhtanen, and B. L. Olafsson. 1995. The AAT/PBV protein evaluation system for ruminants. A revision. Nor. J. Agric. Sci. 19(Suppl.):1-37.

Marini, J. C., J. D. Klein, J. M. Sands, and M. E. Van Amburgh. 2004. Effect of nitrogen intake on nitrogen recycling and urea transporter abundance in lambs. J. Anim. Sci. 82:1157-1164.

Marini, J. C., and M. E. Van Amburgh. 2003. Nitrogen metabolism and recycling in Holstein heifers. J. Anim. Sci. 81:545-552.

Marsh, W. H., B. Fingerhut, and H. Miller. 1965. Automated and manual direct methods for the determination of blood urea. Clin. Chem. 11:624-627.
Mertens, D. R. 2002. Gravimetric determination of amylase-treated neutral detergent fiber in feeds with refluxing in beakers or crucibles: Collaborative study. J. AOAC Int. 85:1217-1240.

Nolan, J. V., and R. A. Leng. 1972. Dynamic aspects of ammonia and urea metabolism in sheep. Br. J. Nutr. 27:177-194.

Ritzhaupt, A., S. Wood, A. A. Jackson, B. J. Moran, and S. P. ShiraziBeechey. 1998. Isolation of a RT-PCR fragment from human colon and sheep rumen RNA with nucleotide sequence similarity to human and rat urea transporter isoforms. Biochem. Soc. Trans. 26:S122. (Abstr.)

Røjen, B. A., P. Lund, and N. B. Kristensen. 2008a. Urea and shortchain fatty acids metabolism in Holstein cows fed a low-nitrogen grass-based diet. Animal 2:500-513.

Røjen, B. A., P. K. Theil, M. Larsen, and N. B. Kristensen. 2008b. Correlation between UT-B mRNA abundance in ruminal epithelium and net portal flux in transition dairy cows. J. Anim. Sci. 86(E-Suppl. 2):T260. (Abstr.)

Sands, J. M. 1999. Regulation of renal urea transporters. J. Am. Soc. Nephrol. 10:635-646.

Satter, L. D., and L. L. Slyter. 1974. Effect of ammonia concentration on rumen microbial protein production in vitro. Br. J. Nutr. $32: 199-208$

Siddons, R. C., J. V. Nolan, D. E. Beever, and J. C. Macrae. 1985. Nitrogen digestion and metabolism in sheep consuming diets containing contrasting forms and levels of N. Br. J. Nutr. 54:175-187.

Simmons, N. L., A. S. Chaudhry, C. Graham, E. S. Scriven, A. Thistlethwaite, C. P. Smith, and G. S. Stewart. 2009. Dietary regulation of ruminal bovine UT-B urea transporter expression and localization. J. Anim. Sci. 87:3288-3299.

Sjaunja, L. O., L. Bævre, L. Junkkarinen, J. Pedersen, and J. Setälä. 1991. A Nordic proposal for an energy corrected milk (ECM) formula. Pages 156-157 in Proc. 27th Session of the International Committee for Recording Productivity of Milk Animals (ICRPMA). Eur. Assoc. Anim. Prod. Publ. No. 50. Eur. Assoc. Anim. Prod., Wageningen, the Netherlands.

Stewart, G. S., C. Graham, S. Cattell, T. P. L. Smith, N. L. Simmons, and C. P. Smith. 2005. UT-B is expressed in bovine rumen: Potential role in ruminal urea transport. Am. J. Physiol. Regul. Integr. Comp. Physiol. 289:R605-R612.

Stewart, G. S., and C. P. Smith. 2005. Urea nitrogen salvage mechanisms and their relevance to ruminants, non-ruminants and man. Nutr. Res. Rev. 18:49-62.

Stoldt, W. 1952. Vorschlag zur Vereinheitlichung der Fettbestimmung in Lebensmitteln. Fette und Seifen 54:206-207.

Sunny, N. E., S. L. Owens, R. L. Baldwin VI, S. W. El-Kadi, R. A. Kohn, and B. J. Bequette. 2007. Salvage of blood urea nitrogen in sheep is highly dependent upon plasma urea concentration and the efficiency of capture within the digestive tract. J. Anim. Sci. 85:1006-1013.

Tebot, I., A. Britos, J. M. Godeau, and A. Cirio. 2002. Microbial protein production determined by urinary allantoin and renal urea sparing in normal and low protein fed Corriedale sheep. Vet. Res. 33:101-106.

Terris, J., C. A. Ecelbarger, J. M. Sands, and M. A. Knepper. 1998 Long-term regulation of renal urea transporter protein expression in rat. J. Am. Soc. Nephrol. 9:729-736.

Theil, P. K., I. L. Sørensen, M. Therkildsen, and N. Oksbjerg. 2006. Changes in proteolytic enzyme mRNAs relevant for meat quality during myogenesis of primary porcine satellite cells. Meat Sci. $73: 335-343$

Thode, S. 1999. Bestemmelse af purinderivater (allantoin, urinsyre, hypoxanthin og xanthin) samt kreatinin i urin hos kvæg ved anvendelse af HPLC (In Danish). DJF Rapport Nr. 127. Danmarks JordbrugsForskning, Foulum, Denmark.

Wickersham, T. A., E. C. Titgemeyer, R. C. Cochran, E. E. Wickersham, and D. P. Gnad. 2008. Effect of rumen-degradable intake protein supplementation on urea kinetics and microbial use of recycled urea in steers consuming low-quality forage. J. Anim. Sci. 86:3079-3088. 